\title{
Macroeconomic Factors and The Correlation of Stock and Bond Returns: Empirical Evidence from Kenya
}

\author{
Isaac Musungu Namango \\ Department of Commerce and Economic Studies \\ Jomo Kenyatta University of Agriculture and Technology Nairobi, Kenya.
}

\begin{abstract}
This paper investigated how macroeconomic factors affect the correlation between stock and bond returns in Kenya over the past decade (July2006-Dec2015) using the Arbitrage Pricing Theory (APT) and Capital Asset Pricing Model (CAPM) framework for a time series of data. The study aimed to validate that the correlation of stock and bond returns could be explained by their common exposure to macroeconomic factors. The link between the stock-bond correlation and macroeconomic factors was examined using OLS regression model. With the empirical tests aimed at answering the following questions: How does inflation affect the correlation between stock and bond returns in Kenya? How do the interest rates affect the correlation between stock and bond returns in Kenya? How does money supply affect the correlation between stock and bond returns in Kenya? And how does the business cycle affect the correlation between stock and bonds? Secondary data obtained from the Kenya Central Bank, the Nairobi securities exchange and the Kenya bureau of statistics from July 2006 - December 2015 was analyzed. The empirical results confirmed that inflation rate, interest rate and business cycle do have a significant and positive influence on the stock-bond correlation. Money supply was found to have a negative influence on stock bond correlation in this study. The Ordinary Least Square Regression Model confirmed long run relationship between stock-bond correlation and the macroeconomic variables under review. The model was found to be robust because it passed all the diagnostic tests.
\end{abstract}

Keywords: Macroeconomic, Stock-Bond Correlation, Co-Movement, Stock, Equity, Bond, Returns, Kenya, Nairobi Securities Exchange, Unit Root, Ordinary Least Squares, Interest rate, Money supply, Business Cycle, Inflation.

\section{Background of the study}

\section{INTRODUCTION}

Correlation analysis between stock and bond returns is one of the important statistical tools that determine diversification strategies in the financial econometrics sector (Shrestha, 2015). Various studies have established that stock-market volatility exhibits substantial variation over time and that stock volatility seems to be excessively based on the time-variation in the volatility of fundamental macroeconomic variables (e.g., (Schwert, 1989); Haugen, Talmor, and Torous, 1991; Whitelaw, 1994; (Campbell, Lettau, Malkiel, \& Xu, 2001)).

A vast school of thought has also tried to understand the co-movements between the stock and bond markets returns (e.g., (Barsky, 1989); Fama and French, 1989; Shiller and Beltratti, 1992; Campbell and Ammer, 1993; and Fleming, Kirby, and Ostdiek, 1998). Changes in return comovements might be due to changing fundamentals (Campbell and Ammer, 1993), crossmarket hedging (Fleming, Kirby, and Ostdiek, 1998), or pricing influences related to timevarying economic uncertainty and possible regime shifting (Veronesi, 1999 and 2001). Baele, Bekaert, \& Inghelbrecht (2010), observe that there is a growing literature documenting this time variation using sophisticated statistical models (see also Guidolin and Timmermann 
2006) but much less work trying to disentangle its economic sources. In particular, the negative stock-bond return correlations observed since 1997 are mostly ascribed to a "flightto-safety" phenomenon (e.g., Connolly, Stivers, and Sun 2005), where increased stock market uncertainty induces investors to flee stocks in favour of bonds. The large negative spikes in realized correlations at the end of 1997 and the end of 1998 are both indeed associated with steep decreases in stock market values, in October 1997, after a global economic crisis scare, and in 1998, in the wake of the Russian crisis and the collapse of the Long Term Capital Management (LTCM). However, the 2002-2003 negative correlations coincide with a deflation scare, where bad real economic prospects drove stock market values lower, while low inflation expectations drove up bond market values. In line with this intuition, Campbell, Sunderam, and Viceira (2009) recently propose a pricing model for stock and bond returns and assign a latent variable to capture the covariance between nominal variables and the real economy, which, in turn, helps to produce negative co-movements between bond and stock returns. Their article asks whether a dynamic factor model in which stock and bond returns depend on a number of economic state variables can explain the average stock-bond return correlation and its variation over time (Baele, Bekaert, \& Inghelbrecht, 2010).

Markowitz (1952) asserts that the estimated conditional correlations are broadly observed to be time varying with huge finance practical applications, such as asset allocation, risk management, and hedging. According to Andersson, Krylova \& Vähämaa (2008), the comovements between stocks and bonds have, for instance, a direct impact on the formulation and implementation of investors' asset allocation and risk management strategies. In particular, investment strategies that assume a constant relationship between stock and bond returns may be improved by properly taking into account the observed time-variation in the correlation between these two asset classes. Furthermore, a better understanding of the timevarying co-movements between stocks and bonds may also be useful for monetary policy purposes. Although central banks do not have specific price targets for financial assets such as bonds or stocks, monetary policy authorities are increasingly using the information contained in the prices of these assets to gauge, for instance, market participants' growth and inflation expectations (Magnus A. et al, 2008).

The importance of correlation estimation has increased in the present day, due to its dynamic nature, especially during highly volatile periods. According to Connolly, Stivers and Sun (2005) and Gulko (2002), the correlation between stock-bond shifts from positive to negative during stock market crashes, referring for enhanced portfolio diversification. Ideally, for diversification purpose correlation needs to move from positive to negative sign, so that investors can obtain decoupling benefits. Decoupling, the return of assets moves in the opposite direction leading to maximization of diversification benefits during market crisis that is the situation when diversification is highly required - due to flight-to-safety phenomena (Gulko, 2002). Flight-to-safety means investors shifting investment from risky assets to nonrisky assets such as treasury bills and bonds as per response towards the sharp fall of stock market (Maslov \& Roehner, 2004).

In addition to the fundamental changes in the macroeconomic environment, financial market dynamics and changes in market participants' assessment about risk may also have an important impact on the relationship between stock and bond returns (Andersson, Krylova, \& Vähämaa, 2008). Gulko (2002) focuses on the stock-bond correlations around stock market crashes, and shows that the periods of negative stock-bond correlation tend to coincide with stock market crashes. In a similar element, Connolly et al, (2005) suggest that option-implied stock market volatility is a good indicator of financial market turmoil. They find that bond 
returns tend to be high (low) relative to stock returns during days when implied stock market volatility is high (low) (Andersson, Krylova, \& Vähämaa, 2008).

Further, a study done on G7 markets (Germany, France, United Kingdom, Switzerland, Japan, Canada and US) by Longin and Solnik (1995) analysed the existence of constant conditional correlation in cross country asset returns through Ljung-Box method and multivariate GARCH $(1,1)$ model. The analyses found both, time variant as well as constant conditional correlation, since Canada and France justified constant conditional correlation hypothesis. Whereas, remaining other countries (Germany, United Kingdom, Switzerland, Japan, and US) rejected the hypothesis and explained the presence of time varying conditional correlation (Longin \& Solnik, 2001). Chui and Yang (2012) presented fusion time-varying conditional correlation while analysing three developed countries; U.S., U.K., and Germany. The positive correlation between stock-bond returns were estimated during both bearish and bullish periods, but the level of correlation was found to be relatively stronger during bearish periods in comparison to bullish period in U.S and U.K markets. However, German market displayed extremely negative correlation, indicating for enhanced diversification opportunities (Chui \& Yang, 2012) (Shrestha, 2015).

In the near past, assets of Emerging Markets (EMs) have attracted high demand among the investors due to two major reasons. Firstly, as noted by (Panchenko \& Wu, 2009), the financial liberalization policy in financial sector plays an important role to shift investment of global investors towards Emerging Markets' assets. Secondly, the undeveloped and premature securities markets of EMs which consist of small-and-medium size listed firms provide higher expected returns and acts as a fascinating factor towards the investors (Eun, Huang, \& Lai, 2008). According to (Shrestha, 2015) participation of external investors in Emerging Markets are able to improve portfolio growth, as well as, gain risk diversification. Despite of such opportunities, very few earlier literatures are focused on co-movement between stock returns and long-term government bond returns, and explained the macroeconomic driving forces behind this relationship in Emerging Markets and more so markets in Africa such as Kenya.

\section{An Overview of the Kenya Stock and Bond Market - Capital Markets}

Long term capital is deemed crucial for economic development as evidenced by the positive relationship between long term capital and economic growth (Demirguc and Levine, 1996). The depth of the financial sector has generally been found to promote economic growth. It has also been observed that well-functioning capital markets increases economic efficiency, investment and growth. Capital market development is an important component of financial sector development and supplements the role of the banking system in economic development. Specifically, capital markets assist in price discovery, liquidity provision, reduction in transactions costs, and risk transfer. They reduce information cost through generation and dissemination of information on firms leading to efficient markets in which prices incorporate all available information ( (Yartey \& Adjasi, 2007), (Garcia \& Liu, 1999)) Moreover, efficient capital markets not only avail resources to investors, they also facilitate inflow of foreign financial resources into the domestic economy. Capital market development therefore enables financial deepening by enabling the savers to diversify their financial asset basket and the firms to have access to alternative sources of financing.

\section{The Kenya Stock Market - Nairobi Securities Exchange}

Nairobi securities exchange - formally Nairobi stock exchange (NSE) was constituted in 1954 as a voluntary association of stockbrokers registered under the Societies Act (NSE, 1997a). It was mandated to develop the stock market and regulate trading activities. The evolutionary process of the NSE can be divided into various developmental stages defined by specific 
institutional characteristics. Stage one is the initiation period before formalization of share trading (1920s-1953) while stage two (1954-1963) is the period when the market was formalized but before the political independence. The post-independence period which constitutes stage three (1964-1970) was the period before the Government made the first attempt to regulate the operations of the market. During stage four, the Government established the Capital Issue Committee (CIC) as a first attempt to oversee the operations of the stock market, (Ngugi, 2003). NSE has undergone gradual development marked by implementation of automated trading system in 2006, uploading of government bonds in the automated system in 2009 and becoming a member of the financial information service division of the software and information industry association (Mutuku, 2015). According to My Stock (2014), the NSE 20-Share Index (NSE 20) is the long-standing benchmark index used for equities traded on Kenya's Nairobi Stock Exchange (NSE) and represents the geometric mean of share prices of the NSE's 20 top stocks. The NSE 20-Share Index was introduced in 1964, one year after African natives were first allowed to trade on the NSE. It was joined in February 2006 by the NSE All Share Index (NSEASI), aimed at reflecting the total market value of all stocks traded on the NSE in one day rather than just the price changes of the 20 best performers captured by the NSE 20. Currently, the NSE has 65 listed companies, Agriculture 7, Automobiles and Accessories 3, Banking 11, Commercial and Services 10, construction and Allied 5, Energy and Petroleum 5, Insurance 6, Investment 5, Investment services 1, Manufacturing and Allied 10, Telecommunication and technology 1 and Real Estate Investment Trust 1(www.nse.co.ke).

\section{The Kenya Bond Market}

Corporate bonds were introduced into the market on November 221996 when the East Africa Development Bank (EADB) bond was issued at a price of 99\% raising Kshs 600 Million. The bond was traded in denominations of Kshs 1 Million with an interest of $1.2 \%$ points above the prevailing 91-day Treasury bill rate. Further the EABD launched a Kshs 2 billion medium term note, which was listed on the NSE Fixed Income securities market segment on 2nd May 2001, which was viewed as a break from the long-term debt instruments. Proceeds from the issue were intended for mobilization and lending in local currencies and for the development of a sustainable tool for alleviating the exchange risk associated with long and medium term borrowing in foreign currencies. The Shelter Afrique made a medium term note of Kshs 350M to be issued in three tranches, the first issued on the 8th December 2000, through a private placement to institutional investors. Proceeds from the sale were used for housing development in Kenya. The first locally controlled firm to offer bond was Safaricom whose proceeds were to be used to expand Safaricom and network coverage and capacity aiming to improve both the availability and reliability of their networks (Ngugi, Amanja, \& Maana, 2006).

The government initially went for short maturity bonds issuing one-year floating bonds, with the first issue made in April 1997. The bond was lowly subscribed, with a subscription of 2.6 billion out of the Kshs 5 billion tendered. Low subscription was attributed to Central Bank failure to give sufficient notice for proper placement of the bond. The nominal annual yield was indexed 2.5 basis points above the 12-week moving average of the 91-day Treasury bill yield and reset quarterly. The government issued floating rate treasury bonds in September 1998 for one and two-year maturity expected to raise Kshs 5 billion. Subscription was low with Kshs 2.8 billion and Kshs 0.5 billion worth respectively. The low subscription was attributed to the liquidity crises among the few small banks during the month. These issues were part of the objective to shift the short term debt consisting mainly of Treasury bills to long term debt and also help address the inverse yield curve. Further, as indicated in 1998/99-budget speech, the government issued tax amnesty bond to encourage compliance with income tax act and a special bond aimed to cover outstanding payments due to the government contractors and 
suppliers was issued. At the same time it was made a requirement that insurance companies should invest a minimum of $25 \%$ of their gross premiums in government securities, to provide liquidity to the bonds market (Ngugi, Amanja, \& Maana, 2006). Maturities of the treasury bonds that have been issued so far range from 1-30 years (www.centralbank.go.ke).

The government has continued to expand borrowing for infrastructure projects by issuing infrastructure bonds and through the successful issuance of the eurobond in 2014, which generated USD 2 billion for the government and was oversubscribed fourfold. As observed by the IMF September 2014 report, the favorable terms of Kenya's first-ever eurobond, the largest so far in sub-Saharan Africa, reflects the favorable position of Kenya relative to other frontier markets. Of the proceeds, USD 600 million were used to repay a syndicated loan contracted in 2012 and the remaining was allocated to finance energy and infrastructure projects. The issuance comprised a five-year bond totaling USD 500 million and a ten-year bond totaling USD 1.5 billion (Odero, Reeves, \& Kipyego, 2015).

\section{Statement of the problem}

According to Ologunde et al., (2006), the stock market plays a major role in financial intermediation in both developed and developing countries. The stock market avail long-term capital to the listed firms by pooling funds from different investors and allow them to expand in business by offering investors alternative investment avenues to put their surplus funds. As an economic institution, the stock market plays a major role of enhancing the efficiency of capital formation and allocation. Thus the overall development of the economy is a function of how well the stock market performs. Empirical evidence has shown that the development of a capital market is essential for economic growth (Ashaolu \& Ogunmuyiwa, 2010). The stock market asset returns experience diverse variations as a result of changes, uncertainty and volatility of several factors in the market (Ologunde, Elumilade, \& Asaolu, 2006). There is no doubt that futures, options and different kinds of derivative products have acquired an ever increasing importance in today's modern financial markets. However, since equities and fixed income securities, primarily corporate and government bonds, remain the major publicly traded financial instruments, accounting for more than a half of financial assets allocated all over the world (as McKinsey Global Institute shows in its 2011 report on global capital markets), the relationship between stock and bond markets takes one of the top researched topics during the last two decades (Murzaieva, 2013). Since the risk-return characteristics of stocks and bonds are very different, stock-bond correlation plays an important role in asset allocation, portfolio management and risk management. Stock prices and hence returns are generally believed to be determined by some fundamental macroeconomic variables such as interest rates, money supply, inflation, exchange rate, and Gross Domestic Product. Changes in stock prices are linked with macroeconomic behavior in advanced countries (Muradoglu et al., 2000).

Several studies explore various economic forces driving stock-bond correlation. Connolly et al. $(2005,2007)$ find that the future stock-bond correlation at higher daily frequency decreases with increasing stock market uncertainty in the US and several other major markets, arguably due to the flight-to-quality phenomenon. The same is confirmed in regard to many European markets by Kim et al (2006). According to d'Addona and Kind (2006), while the volatility of real interest rates may increase the stock-bond correlation in G-7 countries, the inflation volatility tends to reduce the correlation. By contrast an earlier study by Li (2002) argues that both the expected inflation uncertainty and the real interest rate uncertainty tend to increase the correlation between stock and bond returns. 
Boyd et al. (2005) and Andersen et al. (2007) also investigate the effects of macroeconomic news announcements on stock and bond markets in expansions and recessions. They argue that the cash flow effect may dominate during contractions, while the discount rate effect may be more important during expansions, thus resulting in positively correlated stock and bond returns in expansions and lower, perhaps even negative, correlations during recessions. Ilmanen (2003) also proposes a similar argument. By contrast, Jensen and Mercer (2003) document that the monthly correlation between stocks and bonds is lower during expansions than during recessions which is essentially inconsistent with the flight-to-quality argument.

Kirui, Wawire and Onono (2014) posits that most of the African economies are fragile and resilient to both internal and external shocks hence macroeconomic factors are more likely to influence African investments returns (Kirui, Wawire, \& Onono, 2014). Their study however concentrates on the effects of the macroeconomic variables to the stock market returns without specifically looking at how the factors specifically influence the co-movements between stock-bond returns. Most of the previous studies in the Kenyan context focus on the effect of macroeconomic variables on the performance and stock market growth.

In general, despite the fact that the effects of macroeconomic factors on correlations between stock and bond markets are intensively studied, there are no unified conclusions on strength and the direction of this relationship. Conflicting results among studies, obtained occasionally even for the same markets, can be explained by different time periods covered as well as different methodologies applied.

The current study examined the correlation between stock returns and long-term government bond returns, and endeavored to explain the macroeconomic driving forces behind this relationship in the Kenya perspective. The primary contribution of this paper was to test the link between macroeconomic factors and the stock-bond correlation by expanding the usual scope of this literature from developed markets such as the G7 markets, to Emerging markets like Kenya in order to enhance the robustness of the conclusions.

The main objective of this study was to explain the macroeconomic driving forces behind the correlation between stock returns and long-term government bond returns. Specific objectives are to investigate how inflation affects the correlation of stock and bond returns; examine how the interest rate affects correlation of stock and bond returns; investigate how Money supply in the economy affects the correlation of stock and bond returns and investigate how the economic business cycle affects the correlation of stock and bond returns.

\section{Justification of the Study}

Understanding the macroeconomic factor dynamics and their effects on the correlation between stock and bond markets returns is important for several reasons.

To Investors: The effect of macroeconomic factors to the co-movements between stocks and bonds returns have, for instance, a direct impact on the formulation and implementation of investors' asset allocation and risk management strategies. In particular, investment strategies that assume a constant relationship between stock and bond returns may be improved by properly taking into account the observed time-variation in the correlation between these two asset classes.

The Government of Kenya; a better understanding of the effects of variation in macroeconomic factors to co-movements between stocks and bonds may also be useful for monetary policy purposes. Although central banks do not have specific price targets for financial assets such as 
bonds or stocks, monetary policy authorities are increasingly using the information contained in the prices of these assets to gauge, for instance, market participants' growth and inflation expectations. Hence, stock-bond return correlation estimates may offer policymakers useful complementary information to determine whether markets are changing their views on inflation or economic activity prospects.

Academic Researchers: they would benefit from this study as it would serve as a point of reference and a source of literature in their reviews while carrying out further studies on the topic under study more so in emerging markets. The research will add to the body of knowledge on the behavioral relationship between asset returns.

\section{Scope of the study}

Stocks and bonds are still the primary securities traded on stock exchanges and the major component of any optimal portfolio, especially in emerging markets. Since the risk-return characteristics of stocks and bonds are very different, determinants of stock-bond returns correlation plays an important role in asset allocation, portfolio management and risk management. This study will therefore seek to analyze the macroeconomic factors that determine the co-movement between stock and bond market returns in Kenya using weekly total return index of the Stock (Nairobi Securities Exchange Ltd All Share Index NSEASI) and Bond markets (The FTSE NSE Kenyan Shilling Government Bond Index) from January 2000 to December 2015.

The next section reviewed relevant literature while section three discussed research method. Section four contained results and discussions and the paper was completed with conclusions and recommendations in section five.

\section{Theoretical Literature}

\section{LITERATURE REVIEW}

The modern portfolio theory also known as the Markowitz portfolio theory originated from the work of Harry Markowitz who introduced the analysis of the portfolios of investments in his article "Portfolio Selection" published in the Journal of Finance in 1952. Markowitz included portfolio formation by considering the expected rate of return and risk of individual stocks and, crucially, their interrelationship as measured by correlation. Prior to this, investors would examine investments individually, build up portfolios of attractive stocks, and not consider how they related to each other. Markowitz showed how it might be possible to better of these simplistic portfolios by taking into account the correlation between the returns on these stocks. The diversification plays a very important role in the modern portfolio theory. Markowitz approach is viewed as a single period approach: at the beginning of the period the investor must make a decision in what particular securities to invest and hold these securities until the end of the period. Because a portfolio is a collection of securities, this decision is equivalent to selecting an optimal portfolio from a set of possible portfolios. Essentiality of the Markowitz portfolio theory is the problem of optimal portfolio selection (Markowitz, 1959).

When selecting the most desirable portfolio, indifference curves are used. Indifference curves represent an investor's preferences for risk and return. Following Markowitz approach, the measure for investment return is expected rate of return and a measure of risk is standard deviation. Based on the features of indifference curves: All portfolios that lie on a given indifference curve are equally desirable to the investor i.e indifference curves cannot intersect; and that every investor has a map of the indifference curves representing his or her preferences for expected returns and risk (standard deviations) for each potential portfolio (Levišauskaite, 2010). 
There are two important fundamental assumptions when examining indifference curves and applying them to Markowitz portfolio theory: the assumption of non-satiation and the assumption of risk aversion. Under the assumption of non-satiation, investors are assumed to prefer higher levels of return to lower levels of return, because the higher levels of return allow the investor to spend more on consumption at the end of the investment period. Thus, given two portfolios with the same standard deviation, the investor will choose the portfolio with the higher expected return. On the other hand, under the assumption of risk aversion, investors when given the choice will choose the investment or investment portfolio with the smaller risk (Levišauskaite, 2010) (Markowitz, 1959).

As per the Modern Portfolio Theory (MPT), diversification is based on a dictum: "don't put all your eggs in the same basket". MPT explains that combination of two or more than two assets with uncorrelated or weakly correlated returns helps to reduce the risk level by generating volatility lower risk than when these assets are considered independently [for more see Kaplan (1985)]. So, the assets with low or negatively correlated returns are selected in portfolio diversification, in order to reduce the volatility effect without affecting expected return.

Financial economic theory assumes a positive relationship between the risk and return of an investment. The greater the risk taken, the higher the return can be realized and vice versa (Hull, 2012). The tradeoff between risk and return in portfolios of financial investments are actually a tradeoff between risk and expected return, not between risk and actual return. In financial calculations of expected return, the statistical definition of the expected value of a variable is applied (Hull, 2012). This definition states that the expected value of a variable is its average (or mean) value. Expected return is therefore a weighted average of the possible returns, where the weight applied to a particular return equals the probability of that return occurring. The possible returns and their probabilities can either be estimated from historical data or assessed subjectively (Hull, 2012). Based on the MPT theory, investors will be able to diversify their choices between Stocks and Bonds after gauging the expected risks and returns on each and how the returns correlate.

Developed by Sharpe (1964), the Capital Asset Pricing Model (CAPM) simplified Markowitz's Modern Portfolio theory and made it more practical. Lintner $(1965,1969)$ and Mossin $(1966)$, also contributed to the development of this theory as they investigated the effects risk had on the expected return of an investment relative to the market portfolio. Sharpe (1964) discovered that when forming the diversified portfolios consisting large number of securities, investors found the calculation of the portfolio risk using standard deviation technically complicated. Measuring Risk in CAPM is based on the identification of two key components of total risk: Systematic risk and Unsystematic risk. Systematic risk is associated with the market: purchasing power risk, interest rate risk, liquidity risk inter alia. Unsystematic risk is unique to an individual asset such as: business risk, financial risk, and other risks, related to investment into particular asset. Unsystematic risk can be diversified away by holding many different assets in the portfolio, however systematic risk cannot be diversified. In CAPM investors are compensated for taking only systematic risk. Though, CAPM only links investments via the market as a whole.

The essence of the CAPM is that, the more systematic risk the investor carries, the greater is his / her expected return. The CAPM being theoretical model is based on important assumptions: All investors look only one-period expectations about the future; Investors are price takers and they can't influence the market individually; There is risk free rate at which investors may either lend (invest) or borrow money; Investors are risk-averse; Taxes and transaction costs are irrelevant; Information is freely and instantly available to all investors. 
Following these assumptions, the CAPM predicts what an expected rate of return for the investor should be, given other statistics about the expected rate of return in the market and market risk. Several of the assumptions of CAPM seem unrealistic. Investors really are concerned about taxes and are paying the commissions to the broker when buying or selling their securities. And the investors usually do look ahead more than one period. Large institutional investors managing their portfolios sometimes can influence market by buying or selling big amounts of the securities. Overall, the assumptions of the CAPM constitute only a modest gap between the theory and market reality. But the empirical studies and especially wide use of the CAPM by practitioners show that it is a useful instrument for investment analysis and decision making in reality. For instance, Baele et al. (2010) used interest rates, inflation, cash flow growth rate, and the output gap to estimate stock-bond correlation in the U.S. market. Despite of significant results obtained from fundamental approach the Capital Asset Pricing Model (CAPM) of Sharpe (1964) by using inflation, interest rate, and economic growth, in order to interpret the relationship between stock-bond returns. These variables allow performing analysis on long frequency data such as monthly, quarterly, or annually. Unfortunately, such long frequency data are unable to capture the short-run shocks in the financial markets (for example, Bekaert and Grenadier (2001); Mamaysky (2002)). Thus, over the recent years, various advanced and modern tools have been implemented to analyze the short-frequency (weekly, daily, and hourly) asset returns correlation during stock market uncertainty. For example, Connolly et al. (2005) used daily stock and bond return series to examine link between stock-bond co-movement and stock market uncertainty. It presented the negative relation between uncertainty and future co-movement between stock and bond returns.

In a study to validate the model, Fama \& French, (2004), suggested the portfolio theory that investors choose portfolios that are said to be mean-variance-efficient, and found along the efficient frontier for portfolios. The CAPM assumes that any portfolio that is meanvarianceefficient and lies on the efficient frontier is also equal to the market portfolio. The implications of this, according to the authors, are that the relation between risk and expected return for any efficient portfolio must also hold for the market portfolio, if equilibrium is to be maintained in the asset market.

Rose (1976) proposes another form of the CAPM pesented in his article "The arbitrage theory of Capital Asset Pricing", published in Journal of Economic Theory in 1976, what is currently known as the arbitrage pricing theory (APT) in which the return on an asset is specified as a function of a number of risk factors common to that asset class. The model assumes that investors take advantage of arbitrage opportunities in the broader market; thus, an asset's rate of return is a function of the return on alternative investments and other risk factors. The APT in contrast to CAPM acknowledges several sources of risk that may affect an asset's expected return. The key point behind APT is the rational statement that the market return is determined by a number of different factors. These factors can be fundamental factors or statistical. If these factors are essential, there to be no arbitrage opportunities there must be restrictions on the investment process. Here arbitrage we understand as the earning of riskless profit by taking advantage of differential pricing for the same assets or security. Arbitrage is widely applied investment tactic. It is important to note that the arbitrage in the APT is only approximate, relating diversified portfolios, on assumption that the asset unsystematic (specific) risks are negligible compared with the factor risks. There could presumably be an infinitive number of factors, although the economic variables, to which assets having even the same CAPM Beta, are differently sensitive: inflation; industrial production; risk premiums; slope of the term structure in interest rates. In practice, an investor can choose the 
macroeconomic factor that seems important and related with the expected returns of the particular asset.

Chen et al., (1986) in their first empirical investigation of the APT argued that the most basic level some fundamental valuation model determines the prices of assets. That is, the price of a stock will be the correctly discounted expected future dividends. Therefore, the choice of factors should include any systematic influences that impact future dividends, the way traders and investors form expectations and the rate at which investors discount future cash flows.

Jecheche (2006), argues that Multi-factor models allow an asset to have not just one, but many measures of systematic risk. Each measure captures the sensitivity of the asset to the corresponding pervasive factor. The author further contends that, the intuition for the result when assets have no specific risk, is that all asset prices move in lockstep with one another and are therefore just leveraged „copies" of one other. The result becomes more difficult when assets luck specific risk. In such a case it is possible to form portfolios with a diversifiable specific risk. In order to achieve full diversification of residual risk, however, a portfolio needs to include an infinite number of securities. With a finite set of securities, each of which has specific risk, the APT pricing restriction will only hold only approximately.

Ferson and Harvey (1998) however, argue that the CAPM and APT have advantages and disadvantages as models of asset returns. The CAPM is seen as parsimonious and commonly employed by equity analysts, but requires a precious identification of the portfolio against which the asset is compared. On the other hand, Mosley and Singer (2007) contends that, APT accommodates multiple sources of risk and alternative investment, the model suffers from a similar challenge of identification since many factors, both international and domestic could influence an assets performance. The model, as with the CAPM, is subject to certain assumptions; the first of these being that investors may borrow and lend at the risk-free rate, there are no taxes and short selling of securities is unrestricted. The second assumption assumes that a wide variety of securities exist, thus risk unique to those securities may be diversified away, and lastly, investors are risk averse who aim to maximize their wealth. The criticisms of the model have centred on the generality of the APT itself. The APT sets no theoretical foundations for the factors that should be included in ascertaining the risk-adjusted return of the capital asset, and furthermore does not state the number of risk factors that should be included. The APT also presents certain methodological issues relating to the estimation of the model. Cheng (1996) points out that the model may be sensitive to the number of independent variables included in the linear regression. Evidence of this was found by Günsel and Çukur (2007). However, in both cases it was found that the applicability of the APT in establishing asset returns may still be valid.

APT and CAPM can however be explained by a single model as demonstrated by Bailey (2005) "If asset returns are explained by a single factor model, where the single factor is the market rate of return, then the prediction of the APT is identical with that of CAPM. It is possible for the CAPM and APT to be compatible with one another even if the return on the market portfolio is not one of the factors-indeed, even if the factors are not Portfolio return at all." The examples of possible macroeconomic factors which could be included in using APT model: GDP growth; an interest rate; an exchange rate; a default spread on corporate bonds, inter alia. Including more factors in APT model seems logical. The institutional investors and analysts closely watch macroeconomic statistics such as the money supply, inflation, interest rates, unemployment, changes in GDP, political events and many others. Reason for this might be their belief that new information about the changes in these macroeconomic indicators will influence future asset price movements. But it is important to point out that not all investors or 
analysts are concerned with the same set of economic information and they differently assess the importance of various macroeconomic factors to the assets they have invested already or are going to invest. At the same time the large number of the factors in the APT model would be impractical, because the models seldom are 100 percent accurate and the asset prices are function of both macroeconomic factors and noise. The noise is coming from minor factors, with a little influence to the result - expected rate of return.

The APT does not require identification of the market portfolio, but it does require the specification of the relevant macroeconomic factors. Much of the current empirical APT research is focused on identification of these factors and the determination of the factors' Betas. And this problem is still unsolved. Although more than two decades have passed since S. Ross introduced APT model, it has yet to reach the practical application stage. The CAPM and APT are not really essentially different; because they are developed to determine an expected rate of return based on one factor (market portfolio - CAPM) or a number of macroeconomic factors (APT). But both models predict how the return on asset will result from factor sensitivities and this is of great importance to the investor. Therefore, this study will employ the Bayesian Vector Autoregression (BVAR) model to determine the effects of macroeconomic variables (Expected inflation, unexpected inflation and the real interest rate,) on the comovement of stock bond returns in Kenya for the period of 2000 to 2015.

Pioneered by John Maynard Keynes in (1971) the liquidity preference theory states that interest rates change to equate the demand for money with the supply. If demand for money rises, (that is, if people decide they would prefer cash to interest-bearing securities) they sell them, and bond prices fall: i.e. interest rates rise. Likewise, if the supply of money rises people will move into bonds, the price of which will rise: i.e. interest rates fall. A consensus subsequently emerged among most economists that there was a long-run equilibrium rate of interest, representing the expected rate of return required to defer sufficient consumption over a given period (i.e. save) to meet investment demand. However, more contemporary economic thinking has tended to reject the notion of single longrun equilibrium. Instead, concepts such as Professor James Tobinís "Portfolio Selection Theory" focus on the choices made by both firms and households between a wide range of physical or financial assets, each generating varying returns (i.e having different prices). These choices can in turn be affected by all kinds of financial or other event. A real economy, in other words, is a "Spider's web" of complex interconnections, where interest rate levels and their effects cannot be predicted from any simple theory of long-run equilibrium (Keynes, 1971-1989).

Contrary to the neoclassical "special case" interpretation, Keynes considered his liquidity preference theory of interest as a replacement for flawed saving or loanable funds theories of interest emphasizing the real forces of productivity and thrift. His point was that it is money, not saving, which is the necessary prerequisite for economic activity in monetary production economies. Accordingly, turning neoclassical wisdom on its head, it is the terms of finance as determined within the financial system that "rule the roost" to which the real economy must adapt itself. The key practical matter is how deliberate monetary control can be applied to attain acceptable real performance. In this regard, it is argued that Keynes's analysis offers insights into practical issues, such as policy credibility and expectations management, that reach well beyond both heterodox endogenous money approaches and modern Wicksellian orthodoxy, which remains trapped in the illusion of money neutrality (Bibow, 2005). 


\section{Empirical Literature}

\section{Stock-Bond Correlation}

Prior literature is divided into two distinct opinions regarding the relationship of the two assets: First, stock-bond returns are positively correlated, due to involvement of common macroeconomic conditions such as real interest rate, inflation rate, and economic growth situation (Li 2002; Gulko 2002). Second, the presence of negative correlation or shifting from positive to negative co-movement occurs when stock market volatility increases (Baele, Bekaert \& Inghelbrecht 2010; Campbell and Ammer (1993); Connolly et al. 2005; Kim, Moshirian \& Wu 2006). (Shrestha, 2015) explains that during the stock market uncertainty, investors highly oppose the risks as a result bond asset becomes highly attractive in comparison to equity or other riskier assets, so the investors shift capital from stock market to the bond market, perceiving bond as risk free assets, which creates "flight-to-safety" or "flightto-quality" phenomenon (for more De Goeij and Marquering 2004; Baur and Lucey 2009). In contrast, when economies experience expansion in stock market then investors become less risk-averse. Therefore, risky assets or stock market become more attractive towards investor and investment in stock increases, which finally lead to "flight-fromquality" phenomena (Baur \& Lucey 2006). So, these two phenomena seem to be responsible to have negative correlation between stock and bond return. On the other hand, there are some works which indicate mixed signs correlation between asset returns (Yang et al. 2009; Ilmanen 2003). Hence, yet there is an absence of strong evidence in existing literature to answer whether the conditional correlation between stock and bond returns are positively or negatively correlated (Shrestha, 2015).

Various studies have been undertaken using diverse methods in order to understand appropriate joint behaviour between stock and bond markets. Saleem (2011) examined the relationship between the stock and the bond market of Russia. The researcher used multivariate conditional volatility models, such as, Bollerslev (1990) CCC model, Engle (2002) the DCC model, where the author first examined whether the correlations between two classes of assets were constant or time varying. Secondly, he investigated the asymmetries in conditional variances, covariances, and correlations, an asymmetric version of the DCC model proposed by Cappiello et al. (2006) is adopted. The study's empirical results did not support the assumption of constant conditional correlation but there was clear evidence of time varying correlations between the Russian stocks and bond market. Both asset markets exhibited positive asymmetries (Saleem, 2011).

Andersson et al, (2006) examined the impact of inflation and economic growth expectations and perceived stock market uncertainty on the time-varying correlation between stock and bond returns. The empirical analysis in this paper was performed using daily data on US, UK, and German stock and bond returns. The researchers used two methods to measure the timevarying correlation between stock and bond returns: a simple rolling window sample correlation, and the dynamic conditional correlation (DCC) model proposed by Engle (2002). The results of their study indicated that stock and bond prices move in the same direction during periods of high inflation expectations, while epochs of negative stock-bond return correlation seem to coincide with subdued inflation expectations. Furthermore, consistent with the "flight-to-quality" phenomenon, the results suggested that periods of elevated stock market uncertainty lead to a decoupling between stock and bond prices. Finally, this study found that the stock-bond return correlation was virtually unaffected by economic growth expectations (Andersson, Krylova, \& Vähämaa, 2008).

Stivers and Sun (2002) analysed the relationship between stock and bond in short-run by the help of regime-switching models and discovered the flight-to-quality phenomena. This study 
found conditional correlation between asset returns, as well as, that the trade volume of capital market declines during financial turmoil. On the other hand, investors became active in portfolio diversification in order to reduce the risk level associated with specific investment. So, the asset price and mean returns became incompetent to demonstrate the relationship between assets demand, primarily demand of complementary assets, such as bond and equity (Fanga \& Limb 2004).

Chiang, Li, and Yang (2014) considered stock and bond market uncertainty as essential factors which determine the sign of correlation between asset returns. Where, stock market uncertainty led to negative correlation, and positive correlation assumed to be obtained by bond market uncertainty. Similar results were proposed by Connolly et al. (2005), since increase in stock market uncertainty increased demand in bond market. The increase in bond yield believe to bring the downfall in bond and stock prices, thus the correlation is highly determined by bond market risk.

Shrestha (2015) estimates long-run time variant conditional correlation between stock and bond returns of CIVETS (Colombia, Indonesia, Vietnam, Egypt, Turkey, and South Africa) nations. The study further, analyses the presence of asymmetric volatility effect in both asset returns, as well as, obverses increment or decrement in conditional correlation during precrisis and crisis period, which lead to make a reliable diversification decision. The Constant Conditional Correlation (CCC) GARCH model of Bollerslev (1990), the Dynamic Conditional Correlation (DCC) GARCH model (Engle 2002), and the Asymmetric Dynamic Conditional Correlation (ADCC) GARCH model of Cappiello, Engle, and Sheppard (2006) were implemented in the study. The study analyses found strong evidence of time-varying conditional correlation in CIVETS markets, excluding Vietnam, during 2005-2013. In addition, negative innovation effects were found in both conditional variance and correlation of the asset returns. The results of this study recommended investors to include financial assets from these markets in portfolios, in order to obtain better stock-bond diversification benefits, especially during high volatility periods (Shrestha, 2015).

\section{Macroeconomic determinants of the correlation between stock and bond returns}

The determinant factors of the correlation behavior of stock and bond returns has gained extreme emphasis among academics and practitioners, although stock and bond prices, in general, tend to move in the same direction, recent studies have also documented sustained periods of negative correlation. Stock and bond prices are the discounted sums of their future cash flows. Assuming there is no default risk, a stock's cash flow is an infinite stream of uncertain dividends, while a bond's cash flow is a fixed number of payments of predetermined coupon income. Evidently, factors that exclusively affect the discount rates are likely to move stocks and bonds in the same direction, while those affecting only stock dividends will reduce their co-movement (Li, 2002).

Altay (2003) conducted a study on the effect of macroeconomic factors on asset returns where a comparative analysis of the German and the Turkish stock markets was done in an APT framework. This paper used factor analytic techniques to derive factor realizations from a group of main economic indicators where the German economy yielded 4 factors, whereas the Turkish economy had only 3 factors even though the same economic indicators were employed in the factor analysis procedures. This study found some evidence of the unexpected interest rate factor and the unexpected inflation factor beta coefficients having significant effects on asset returns of the German Stock Market, but was not able to find any unexpected macroeconomic factor beta with a significant influence on asset returns in the Turkish Stock Market (Altay, 2003). 
Zhu (2012) in the study "the effects of macroeconomic factors on stock return of energy sector in shanghai stock market" investigated the inflation rate, money supply (M2), exchange rate, industrial production, bond, exports, imports, foreign reserve and unemployment rate. The secondary data, collected from People's Bank of China and the National Bureau of Statistics of China, were for the period beginning January 2005 to December 2011 with no any missing monthly observations. This study found that the exchange rate, exports, foreign reserve and unemployment rate have effects on the stock return of energy sector in Shanghai stock market (Zhu, 2012).

Aslanidis and Christiansen (2014) provide new insights into the role of macroeconomic fundamentals in explaining stock-bond correlations. They find that macroeconomic factors have only little explanatory power when the stock-bond correlation is largely positive; but when the stock-bond correlation is largely negative, then macroeconomic fundamentals are most useful explanatory variables. The rationale behind this finding is that macroeconomic factors are important for bonds in all periods, while for stocks they are important only in extremely volatile periods (Aslanidis \& Christiansen, 2014).

Dimic, et al (2014) carried out a study on the impact of financial market uncertainty and macroeconomic factors on stock-bond correlation in emerging markets using data from 10 emerging markets (Argentina, Brazil, Bulgaria, Colombia, Mexico, Peru, Philippines, Russia, Turkey and Venezuela) and the U.S. spanning from January 2001 to December 2013, leading to the sample size of 156 observations for all markets included in the study. The study employs the wavelet analysis approach; which enable the researchers to examine stock-bond correlations over different time horizons in ten emerging markets. The study found that stockbond correlation patterns vary significantly between the time horizons. In particular, the correlation in short horizon changes the sign rapidly showing sustainable negative episodes while the correlation in long horizon stays positive most of the time. The study also concluded that the most important factor influencing stock-bond correlation in short horizon is the monetary policy stance, while the factors with the greatest long-term impact are inflation and stock market uncertainty. Finally, global stock market uncertainty played a more significant role than global bond market uncertainty in explaining stock-bond correlations in emerging markets (Dimic, Kiviaho, Piljak, \& Äijö, 2014).

This study examined the following macroeconomic factors and how they influenced the correlation of stock-bond returns:

\section{Inflation rate and correlation of stocks and bond returns}

The inflation rate is the rate of increase of a price index (for example, a consumer price index). It is the percentage rate of change in price level over time. The rate of decrease in the purchasing power of money is approximately equal (Mishni, 2004). The effects of inflation as a macroeconomic factor on the financial markets and the aggregate economy are diverse and can be both positive and negative. The negative effects are however most pronounced and comprise a decrease in the real value of money as well as other monetary variables over time. Several scholars have used different models to examine the effect of inflation on correlation of stock bond returns.

Fama and Schwertz (1977) did a study to estimate the extent to which various assets were hedges against the expected and unexpected components of the inflation rate during the 19531971. Their study found that U.S. government bonds and bills were a complete hedge against expected inflation and private residential real estate was a complete hedge against both expected and unexpected inflation. The authors also found that labor income showed little short-term relationship with either expected or unexpected inflation. The most 
anomalous result is that common stock returns were negatively related to the expected component of the inflation rate, and probably also to the unexpected component. Baele et al (2010) noted that Inflations and the output gap can affect the real term structure of interest rates and therefore affect both bond and equity prices. Because equities represent a claim on real assets, the discount rate on stocks should not depend on nominal factors such as expected inflation. Yet, a recurring finding is that stocks seem to be very poor hedges against inflation and their returns correlate negatively with inflation shocks and expected inflation (Fama \& Schwertz, 1977).

Li (2002) investigates how macroeconomic factors affect the correlation of stock-bond returns using data from G7 countries (U.S., the U.K., France, Germany, Japan, Canada and Italy). The data analysed started from 1958 to 2001 . The asset pricing model was used which shows that stock and bond returns can be explained by their common exposure to macroeconomic factors. The link between the stock-bond correlation and macroeconomic factors is examined using three successively more realistic formulations of asset return dynamics. Their empirical results indicated that the major trends in stock-bond correlation were determined primarily by uncertainty about expected inflation. On the impact of uncertainty about expected long-term inflation on stock-bond return correlation, Li (2002) shows that greater concerns about future inflation tend to result in stronger co-movements between stocks and bonds. About expected inflation rate, Li (2002) noted that similar to the real interest rate, expected inflation moves stock and bond returns in the same direction. Greater uncertainty about this factor is likely to cause higher co-movement. Greater uncertainty about expected inflation and the real interest rate increases this correlation. In addition, uncertainty about the stock unique component reduces the stock-bond correlation by changing the volatility of stock returns. According to Li (2002), it is important to note that it is the uncertainty, rather than the levels, of the macroeconomic factors that affects the stockbond correlation. Li (2002) concludes that if the economy is neutral to unexpected inflation shocks, then we expect the stock-bond correlation to decrease with higher uncertainty about unexpected inflation. Otherwise, the effect of unexpected inflation shocks cannot be determined. The effect of unexpected inflation is ambiguous and depends on whether the dividend yield and the real interest rate are affected by unexpected inflation shocks.

Ilmanen (2003) uses US data on stock and bond returns from 1929 to 2001 to examine the impact of inflation on the correlation between stock and bond returns, and finds that during periods of high inflation, changes in the discount rates dominate the changes in cash flow expectations, thereby inducing a positive stock-bond return correlation. The researcher explains that inflation rates had a large impact on stock and bond price correlation. When inflation rates were high, changes in the discount rate moved stock and bond prices in the same direction. When inflation was low, discount rates were relatively stable and economic uncertainty was tied to growth. As a result, the correlation between bond and stock returns decreased. In a period of deflation, the author suggests that stock-bond correlation may be negative because equity risk premiums rise and bond risk premiums decrease. He cites Japan as an example of negative correlation of stock and bond prices in a deflationary environment (Ilmanen, 2003).

Andersson et al. (2008) use data from the US, the UK, and German markets and find that inflation expectation is an important determinant of the stock-bond correlation, while economic growth expectation is not a relevant factor. Specifically, their result shows that stock and bond prices move in the same direction when inflation expectations are high (Andersson, Krylova, \& Vähämaa, 2008). 
Yang, Zhou and Wang (2009) conducted a study titled "The stock-bond correlation and macroeconomic conditions: One and a half centuries of evidence" using monthly stock and bond return data over a 150 years' period (1855-2001) for both the U.S. and the U.K., this study documented time-varying stock-bond correlation over macroeconomic conditions (the business cycle, the inflation environment and monetary policy stance). The study observed different patterns of time variation in stock-bond correlations over the business cycle between U.S. and U.K., which implied that bonds may be a better hedge against stock market risk and offer more diversification benefits to stock investors in the US than in the UK. Further, found a general pattern across both the U.S. and the U.K. during the post-1923 subperiod and during the whole sample period: higher stock-bond correlations tend to follow higher short rates and (to a lesser extent) higher inflation rates (Yang, Zhou, \& Wang, 2009).

Baele et al, (2010) studied the economic sources of stock-bond return co-movements and their time variation using a dynamic factor model on US data from 1970 - 2005. They identified the economic factors employing a semi structural regime-switching model for state variables such as interest rates, inflation, the output gap, and cash flow growth. They also viewed risk aversion, uncertainty about inflation and output, and liquidity proxies as additional potential factors. The study found that macroeconomic fundamentals contributed little to explaining stock and bond return correlations but that other factors, especially liquidity proxies, played a more important role. The macro factors were found to be still important in fitting bond return volatility, whereas the "variance premium" was critical in explaining stock return volatility. However, the factor model primarily failed in fitting covariances (Baele, Bekaert, \& Inghelbrecht, 2010).

Zhou and Jeske (2012) conducted a study called "Unexpected Inflation Hedging: A 3D SUPER Approach" using U.S. data from January 1970 to June 2012. They argue that the most important type of inflation impacting asset returns is the unexpected, or surprise inflation because asset prices have already incorporated expectations on growth, inflation, and earnings, inter alia and that it is the surprise that moves the markets near term. The authors posit that high inflation may not be detrimental to bond returns if the expectations have already been incorporated into asset prices. Incidentally, some of the highest bond returns occurred in the early $1980 \mathrm{~s}$ (April 1982 to April 1983: +35\%) when expected inflation was still high but realized inflation surprised on the downside when the Fed, managed to get inflation under control. Zhou and Jeske (2012) conclude that what matters for asset prices is the inflation above or below what was expected, that is the unexpected inflation. On the reaction of asset classes to unexpected inflation, Zhou and Jeske (2012) assessed the sensitivities for unexpected inflation betas using U.S. data from January 1970 to June 2012 and found that nominal bonds had a large negative unexpected inflation beta. Zhou and Jeske (2012) explained that nominal bond returns typically reacts negatively to unexpected inflation when short-term interest rates rise and lift up the entire interest rate term structure. Through duration this effect is multiplied and incorporated into bond prices at longer maturities. On the effect to returns on equities, the authors explain that also stock returns have negative unexpected inflation betas despite sufficient literature on the view that equities are an inflation hedge in the very long-term (Ahmed, Salman, \& Mirko, 2005) and (Mishkin, 1992), unexpected inflation still negatively affects equities in the short term. Zhou and Jeske (2012) concludes that due to countercyclical monetary policy, inflation adversely affects equity prices when financial markets price in the impact of tighter monetary policy and thus a cooling down of the economy (Zhou \& Jeske, 2012). 


\section{Interest rates and correlation of stocks and bond returns}

The interest rate can be defined as the annual price charged by a lender to a borrower in order for the borrower to obtain a loan. This is usually expressed as a percentage of the total amount loaned. Traditional theories define interest rate as the price of savings determined by demand and supply of loanable funds. According to John Maynard Keynes, interest rates were generally set in the market for loans. Other factors, however, were important: in particular, the liquidity preference of savers. The interest rate was determined by the level of reward they demanded for tying up their money in bonds or other assets rather than keeping it in cash. If savers believed that prices would fall (including those of financial assets), they would keep their money in cash. Hence the liquidity preference theory states that interest rates change to equate the demand for money with the supply. If demand for money rises, (that is, if people decide they would prefer cash to interest-bearing securities) they sell them, and bond prices fall: i.e. interest rates rise. Likewise, if the supply of money rises people will move into bonds, the price of which will rise: i.e. interest rates fall. A consensus subsequently emerged among most economists that there was a long-run equilibrium rate of interest, representing the expected rate of return required to defer sufficient consumption over a given period (i.e. save) to meet investment demand. However, more contemporary economic thinking has tended to reject the notion of single longrun equilibrium. Instead, concepts such as Professor James Tobinís "Portfolio Selection Theory" focus on the choices made by both firms and households between a wide range of physical or financial assets, each generating varying returns (i.e having different prices). These choices can in turn be affected by all kinds of financial or other event. A real economy, in other words, is a "Spider's web" of complex interconnections, where interest rate levels and their effects cannot be predicted from any simple theory of long-run equilibrium.

Ngugi and Kabubo( 1998) state that the primary role of interest rate is to help mobilize financial resources and ensure the efficient utilization of resources in the promotion of economic growth and development (Olweny \& Omondi, 2011). Adam \& Tweneboah, (2008) assert that, first, if an investor considers interest rate as cost of capital, an increase or a decrease in interest rate may affect the investment decision of the investors. For example, when there is a rise in interest rate and the opportunity cost goes up, individual investors would prefer to invest in non-fixed income securities such as bonds (Adam \& Tweneboah, 2008). This may result either in profit or loss which is reflected in the firm's balance sheet. When the profit or loss of a firm is immediately announced, the stock price of a firm will increase or decrease. This implies that the valuation of a firm would either increase or decrease its stock price hence stock returns.

Campbell and Ammer (1993) employ a VAR to decompose the variance-covariance matrix of excess stock and bond returns. They identify two components that govern the stock-bond covariance: while unexpected shocks of the real interest rate drive returns of stocks and bonds in the same direction, expected inflation increases excess stock returns and lowers excess bond returns. Campbell and Ammer (1993) find that, for post-war US data, realized correlations are remarkably low. According to these authors, this can be explained by the low variability of real interest rates and by increases in expected inflation which drive correlation down (Campbell \& Ammer, 1993).

Li (2002) in the study investigating how macroeconomic factors affect the correlation of stockbond returns using data from G7 countries (U.S., the U.K., France, Germany, Japan, Canada and Italy from 1958 to 2001 emphasized the uncertainty about the real interest rate where they explain that higher uncertainty about the real interest rate tends to increase the comovement of stock and bond returns. The study found that the real interest rate determines how an 
investor discounts stock and bond cash flows therefore concluding that interest rate shocks are likely to move stock and bond prices in the same direction (Li, 2002). Li (2002) argues that both the expected inflation uncertainty and the real interest rate uncertainty tend to increase the correlation between stock and bond returns. By contrast, d'Addona and Kind (2006) show that although the volatility of real interest rates may increase the stock-bond correlation in G-7 countries, the inflation volatility tends to reduce the correlation.

\section{Money supply and the correlation of stock and bond returns}

Monetary policy is one of the most effective tools that a central bank has at its disposal. The central bank uses monetary policy frequently to cause a desired level of change in real activities. These frequent changes in monetary policy are believed to have a significant effect on the financial market. It is important to analyze the relationship between the most effective economic policy, namely monetary policy, and one important determinant of the economy, the financial market (Maskay, 2007). Specifically, the relationship between the money supply and stock market prices and hence returns for bonds and equities. The price of a stock is determined by the present value of the future cash flows. The present value of the future cash flows is calculated by discounting the future cash flows at a discount rate. Money supply has a significant relationship with the discount rate and, hence, with the present value of cash flows (Maskay, 2007). According to Sellin (2001), money supply affects stock prices only if the change in money supply alters expectations about future monetary policy. The author argues that a positive money supply shock will lead people to anticipate tightening monetary policy in the future. The subsequent increase in bidding for bonds will drive up the current rate of interest. As the interest rate goes up, the discount rates go up as well, and the present value of future earnings decline (Sellin, 2001). As a result, stock prices decline. Furthermore, Sellin (2001) argues that economic activities decline as a result of increases in interest rates, which further depresses stock prices.

Ilmanen (2003) examined the correlation of U.S. stock and bond returns from 1929 to 2001. The author found that the correlation had been slightly positive over time, with intermittent periods of divergence. He finds that the major factors influencing the correlation between stock and bond returns are economic and monetary policy cycles, inflation rates, and volatility shocks. He emphasizes that an understanding of stock-bond correlations is important for longterm asset allocation decisions (Ilmanen, 2003). Fah (2008) studied the impact of several macroeconomic factors to the yield spreads between two Malaysian Government Securities (MGS) and 10-year MGS. The study found that GDP growth rates, industry production and money supply ratio are positively related to MGS yield spreads (Fah, 2008).

Carr and Smith (1972) in their Journal of Money, Credit and Banking investigated Money Supply, Interest Rates, and the Yield Curve using quarterly observations on Canadian data over the period 1Q 1952 to 4 Q 1969. In this study, the authors examine how changes in the money supply affect nominal interest rates through changes in the real rate of interest and through changes in the expected rate of inflation, and empirically estimate these effects of money on interest rates. In so doing they also investigated the effects of money on short, medium, and long-term interest rates and derive the real yield curve. This study concludes that: unexpected monetary changes have a significant but temporary impact on real interest rates, with the greatest impact occurring on the short-end of the market; an increase in expectations of inflation leads to a significant increase in nominal interest rates; interest rates adapt relatively quickly to changes in the rate of inflation, the average lag being 12 to 2 years for short term interest rates and 2 to 3 years for long term interest rates and that the model formulated can be used to calculate real interest rates. The term structure for real interest rates resembles closely the term structure for nominal rates (Carr \& Smith , 1972). Therefore, depending on the 
effect of money supply on the inflation and real interest rates, the two components that govern the stock-bond covariance: unexpected shocks of the real interest rate will drive returns of stocks and bonds in the same direction, expected inflation will increase excess stock returns and lower excess bond returns (Campbell \& Ammer, 1993).

Reilly and Brown (2000) in their book on investment analysis and portfolio management stated that increasing prices could severely affect bond prices if, of course, they are not indexed to inflation. This occurs when the rise (decline) of inflation puts an upward (downward) pressure on the required return of investors who want to keep the same real return on investment. In the case of emerging markets, inflation is also showed to be a leading indicator of the balance of payment crises and as a proxy for the quality of economic management thus directly influencing the sovereign default risk. This effect is particularly known due to the rule of Taylor (1993) who states that a 1\% increase in inflation should prompt the central bank to raise the nominal interest rate by more than $1 \%$, which should undoubtedly negatively affect the government bond prices. In addition, the increase of money supply can lead to a higher inflation in the future, so the quantity of money can predict the future consumer price movements and have the same effect on debt securities as inflation has. However, a share of increased money supply can be directed to debt securities markets, i.e. increasing the demand and the prices (Reilly \& Brown, 2000).

\section{Business Cycle and the correlation of stock and bond returns}

According to Li (2002), many researchers argue that business cycles have a strong effect on asset returns (e.g., Rouwenhorst 1995) and international equity correlations (e.g., Erb,Harvey, and Viskanta 1994). Schwert (1989) shows that they can explain much of the time series variations in the stock return volatility. Therefore, a natural question is whether the stockbond correlation varies at different stages of the business cycle. Li (2002) used the business cycle dates of Economic Cycle Research Institute (ECRI), who applied the same methodology used by NBER to the business cycles dating for major industrial countries. The author's results indicate that business cycle on effect on the stock-bond correlation, either in the U.S. or in the G7 panel (Li, 2002).

Dimic et al (2014) in their study on "the impact of financial market uncertainty and macroeconomic factors on stock-bond correlation in emerging markets" analyzed business cycle patterns as one of the domestic macroeconomic factors influencing stock bond correlation in the emerging markets, namely Argentina, Brazil, Bulgaria, Colombia, Mexico, Peru, Philippines, Russia, Turkey and Venezuela. In this study, the researchers used industrial production index as a proxy for domestic business cycle fluctuation. The study found business cycle to be the third influential macroeconomic factor for the stock-bond correlation in the long run, appearing significant in eight emerging markets under their review. Estimated coefficients of the industrial production index were positive and statistically significant in seven countries, specifically Argentina, Bulgaria, Colombia, Peru, Russia, Turkey and Venezuela. This result indicated that the domestic trend in growth may have similar effect on stock and bond returns in the long run, causing a positive correlation (Dimic, Kiviaho, Piljak, \& Äijö, 2014).

Another study conducted by Durnez (2016) investigating if stock-bond return correlation in the BRIC countries is affected by their economic expansion. Durnez (2016) include industrial production as a proxy for business cycle like Dimic (2014). This study did not find business cycle to be a significant determinant of stock-bond correlation in BRIC countries, with the industrial production (their proxy for the business cycle) turning out to be only significant in two countries (Durnez, 2016). 


\section{Conceptual Framework - defining the economic variables}

Inflation (INF): It is a persistence increase in general prices of goods and services. Measured by quarterly percentage change in consumer price index. Month on month inflation data is obtained from the Kenya central bank website ranging from July 2006 to December 2015.

Interest Rate (INT): The 91-day Treasury bill rate is used as a proxy for domestic rate of interest. A 30 day moving average is computed from the daily rate provided on the central Kenya of bank website.

Money Supply (M3): A measure of aggregate money supply that includes M1 and long-term money deposits. Measured by quarterly average of money supply. Monthly data is provided on the Kenya Central Bank Website.

The Business Cycles: These are the ups and downs in economic activity, defined in terms of periods of expansion or recession. During expansions, the economy, measured by indicators like jobs, industrial production, and sales, is growing in real terms, after excluding the effects of inflation. Recessions are periods when the economy is shrinking or contracting. Industrial Production (IP yoy growth rate); is included in this study as a proxy for the business cycles.

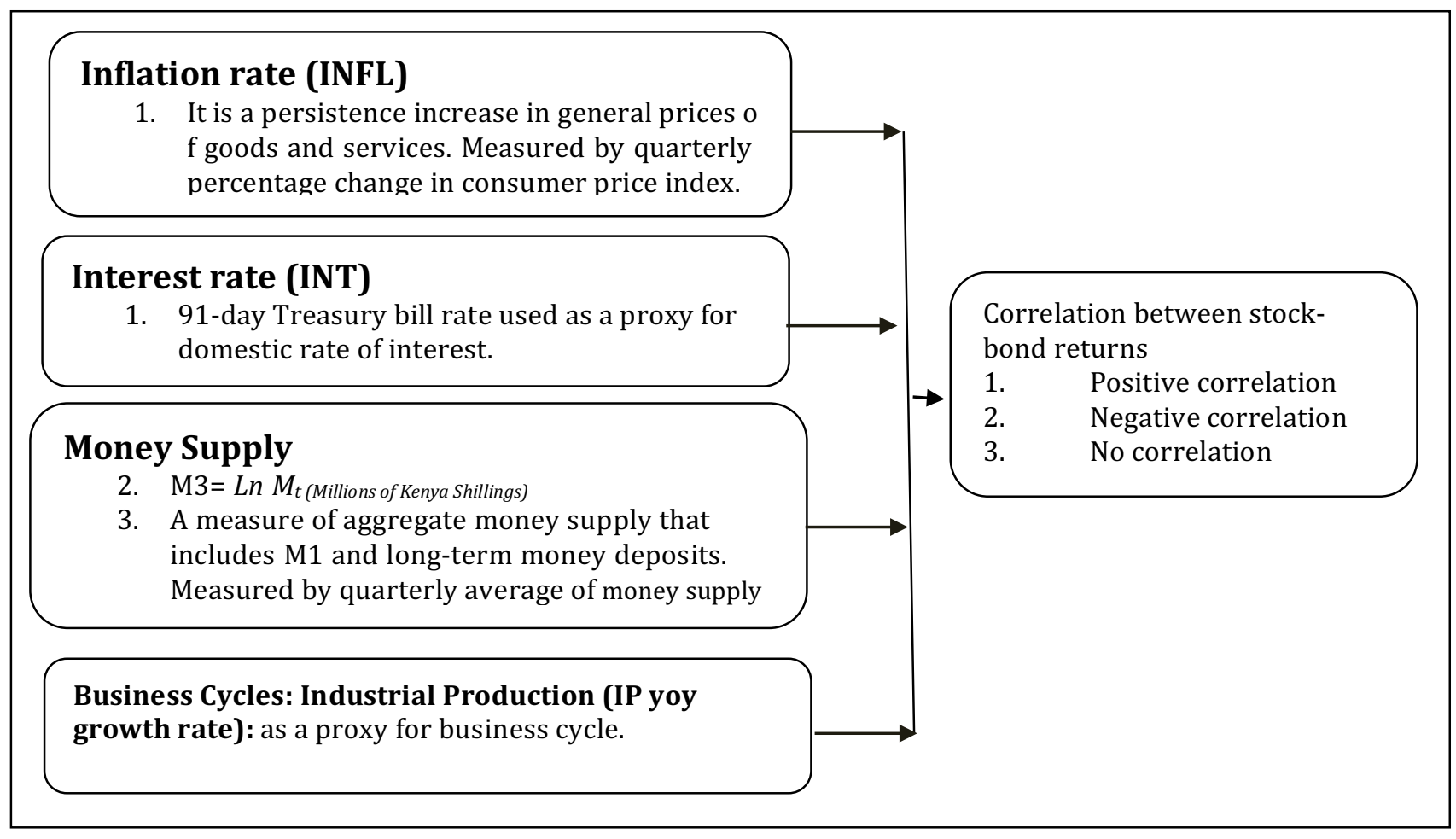

Figure 1: Conceptual Framework

\section{Research Gap}

A few key conclusions can be drawn from this literature review. Foremost, while existing theories assume a link between macroeconomic variables and the correlation between stock and bond returns, they do not specify the type or the number of macroeconomic factors that should be incorporated. Thus, the existing empirical studies, reviewed in this chapter, have shown the use of a vast range of macroeconomic variables to examine their influence on the correlation between stock and bond returns. The prior studies have also significantly enhanced our understanding of the link between financial markets and real economic activity, the findings from the literature are mixed given that they were sensitive to the choice of countries, variable selection, and the time period studied. It is difficult to generalize the results because 
each market is unique in terms of its own rules, regulations, and type of investors. Still on Kenyan markets, of the reviewed literature, no specific one has attempted to scrutinize the effects of macroeconomic variables on the correlation between stock and Bond returns. Therefore, this study, to the best of my knowledge, is among the first empirical studies to consider the relationships between the Kenyan stock and bond returns and a set of macroeconomic variables from July 2006 to December 2015.

\section{Research Design}

\section{RESEARCH METHODOLOGY}

An explanatory design helps us to provide an explanation of causal relationships between variables, in this case macroeconomic factors and correlations between stock and bond market returns. Time-series regression analysis was employed to analyze the uncertainty, volatility and correlation which are very important aspects when the central issue is return of assets or investment for any financial activities.

\section{Data Source}

This study used secondary data from NSE, Kenya National Bureau of Statistics and the Central Bank of Kenya. Additional data obtained from published financial journals, internet, and relevant textbooks. Data on macroeconomic variables was obtained from the Kenya bureau of statistics. For the purposes of this study, monthly moving average return index of the Stock (Nairobi Securities Exchange 20 Index NSE20) and Bond markets (The FTSE NSE Kenyan Shilling Government Bond Index from July 2006 to December 2015) was computed for analysis.

\section{Data Analysis and Procedures}

The data that was used in this study comprised of indices from national stock and bond markets. The stock market data composed of commonly used stock indices for companies listed in the NSE 20. Both Quantitative and qualitative data was generated from the secondary data sources. The date imported into excel spreadsheets and then exported and analyzed using descriptive statistics by use of Eviews which enabled the researcher to draw conclusions and references. The quantitative data was further analyzed using descriptive statistics (frequency distributions, and percentages) and qualitative data was transformed into quantitative data by the way of tallies and frequency distribution and analyzed in the same way. Data was finally presented using tables and graphs. In order to establish the relationship between Macroeconomic factors and the co-movement between equity and bonds, the researcher conducted regression analysis.

\section{Model specification}

Firstly, the study identified significant macroeconomic variables in Kenya. The variables included in the model were variables which were found to be influential in previous research (Business Cycle/Industrial production, inflation and interest rate). Money Supply has been added to provide a view of the specific monetary policy environment in the country. The ordinary least squares method was employed to estimate the coefficients.

$$
\text { YCorr }_{t}=\beta_{1}+\beta_{2} \cdot I_{N F L}+\beta_{3} \cdot I N T T_{t}+\beta_{4} \cdot I P_{t}+\beta_{5} \cdot M^{t}+\varepsilon_{t}
$$

Where:

YCorr = stock-bond return correlation

INFL = Inflation rate

INT = Interest Rate

IP = Industrial Production (yoy growth percentage) proxy for Business cycles 
M3 =Money Supply

$\varepsilon \mathrm{t}=$ Error Term

\section{RESEARCH FINDINGS AND DISCUSSION}

\section{Descriptive Statistics for Variables}

The tool used to determine the macroeconomic factors affecting correlation between stock bond returns includes descriptive statistics, the unit root Augmented Dickey Fuller (ADF) test proposed by Dickey and Fuller $(1979,1981)$.

Table 4.1: Descriptive Statistics of Kenya Stock and Bond Returns July 2006 -Dec 2015

\begin{tabular}{lcc}
\hline & BOND10YR & NSE20 \\
\hline Mean & 11.92197 & 4373.919 \\
Median & 11.97200 & 4539.775 \\
Std. Dev. & 2.110392 & 782.4322 \\
Skewness & -0.351983 & -0.382862 \\
Kurtosis & 4.803533 & 2.132103 \\
Jarque-Bera & 17.80442 & 6.363000 \\
Probability & 0.000136 & 0.041523 \\
\hline Observations & 114 & 114 \\
\hline Stock-Bond Correlation & & NSE20 \\
\hline BOND10YR & BOND10YR & -0.146277 \\
NSE20 & 1.000000 & 1.000000 \\
\hline
\end{tabular}

\section{Source: Author Computation}

Table 4.1 above show both the variables Kenya Government 10-year Bond and the NSE 20 gave positive monthly mean of 11.92 and 4373.92 respectively. The results are in line with the tradeoff notion risk and return in which the higher yield by stocks as a means to compensate for the instrument's risk exposure. The high standard deviation intended to measure the volatility and riskiness of the instrument also shows higher standard deviation of the Stocks (NSE20). Compared with stock market, the bond market demonstrates a more leptokurtic curve which conforms to the regular pattern that bond returns generally have smaller volatile than stock returns, which also means that bond market has lower risk than stock market. It also indicates that the Kenya govrnment10yr bond yields are negatively correlated to the NSE20 returns with correlation coefficient of -0.1463 .

The general negative relationship is depicted in figure 4.1 below. 


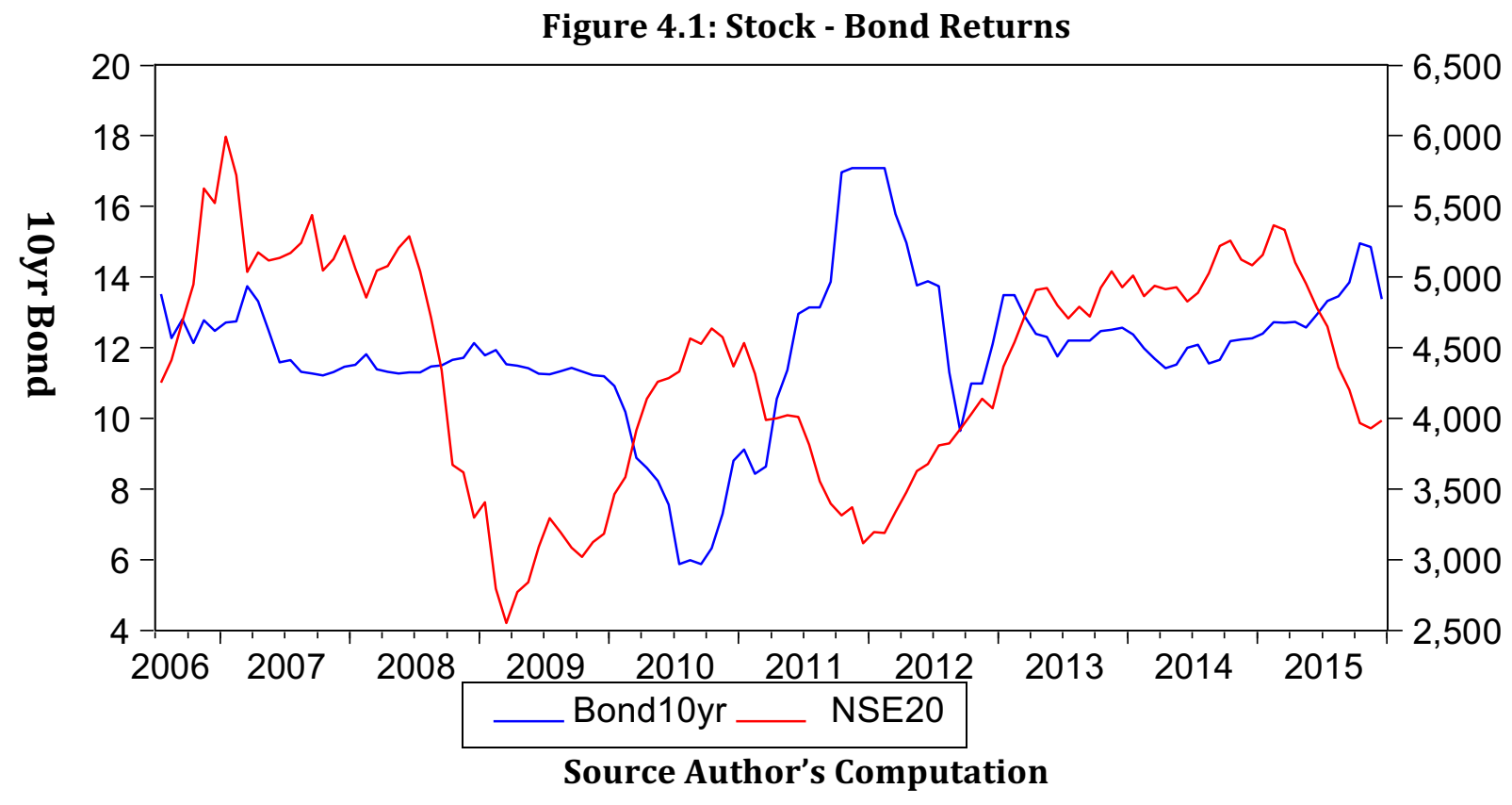

Table 4.2: Descriptive Statistics of Macroeconomic Variables

\begin{tabular}{|c|c|c|c|c|}
\hline & INT & INFL & IP_GROWTH_RATE & M3 \\
\hline Mean & 8.300526 & 8.385263 & 4.661842 & 1.310778 \\
\hline Median & 7.895000 & 6.630000 & 4.140278 & 1.224257 \\
\hline Std. Dev. & 3.625153 & 4.899578 & 1.344412 & 1.193193 \\
\hline Skewness & 1.248182 & 1.020051 & 0.818754 & 0.380423 \\
\hline Kurtosis & 5.991106 & 2.796468 & 2.684904 & 6.186520 \\
\hline Jarque-Bera & 72.09811 & 19.96634 & 13.20840 & 50.98078 \\
\hline Probability & 0.000000 & 0.000046 & 0.001355 & 0.000000 \\
\hline Observations & 114 & 114 & 114 & 114 \\
\hline \multicolumn{5}{|l|}{ Correlations } \\
\hline & INT & INFL & IP GROWTH RATE & M3 \\
\hline$I N T$ & 1 & & & \\
\hline INFL & 0.4324 & 1 & & \\
\hline IP GROWTH RATE & 0.0030 & -0.3507 & 1 & \\
\hline M3 & -0.1706 & -0.1018 & -0.0367 & 1 \\
\hline
\end{tabular}

Table 4.2 above show the average Inflation rate as $8.38 \%$. The average interest rate stood at $8.30 \%$. Industrial production growth rate averaged at $4.66 \%$ while the M3 growth rate averaged at $1.31 \%$.

\section{Unit Root Test}

As noted by (Kirui, Wawire, \& Onono, 2014), an important concern in data analysis is to determine whether a series is stationary (do not contain a unit root) or not stationary (contains a unit root). Time series data are often assumed to be non-stationary and thus it was necessary to perform a pretest to ensure that all the variables were stationary in order to avoid the problem of spurious regression (Granger, 2001). 
Table 4.3: Unit root test for monthly stock -bond returns and the macroeconomic variables

\begin{tabular}{lllll}
\hline & \multicolumn{2}{c}{ Level } & \multicolumn{2}{c}{ First difference } \\
\hline Variables & Constant & Constant \& Trend & Constant & Constant \& Trend \\
\hline BOND10YR & -2.4665 & -2.5449 & $-7.6679^{* * *}$ & $-7.6061^{* * *}$ \\
NSE20 & -18272 & -1.8159 & $-8.1127^{* * *}$ & $-8.0764^{* * *}$ \\
INFL & -2.2474 & -2.7007 & $-5.5564^{* * *}$ & $-5.5180^{* * *}$ \\
INT & -2.4583 & $-3.2518^{*}$ & $-4.8346^{* * *}$ & $-4.8124^{* * *}$ \\
IP growth rate & -2.1891 & -1.3463 & -0.6847 & -1.6274 \\
M3 & $-11.9042^{* * *}$ & $-11.8785^{* * *}$ & $-11.0374^{* * *}$ & $-10.9801^{* * *}$ \\
\hline
\end{tabular}

Note: ${ }^{* * *}$ and ${ }^{* * *}$ indicates rejection of the null hypothesis at level of confidence $10 \%$, $5 \%$ and $1 \%$ respectively

\section{Source: Author's computation}

The results indicate that the null hypothesis of the presence of unit root cannot be rejected at level in all the variables except for the Money supply month on month growth percentage M3 which shows that at level, the t-statistics is statistically significant at $1 \%$ level. At first difference, the null hypothesis can be rejected in the Bond10yr, NSE20, Inflation and interest rates, with the t-statistics statistically significant at $1 \%$ level. This indicates that at first difference all series are stationary when tested with trend or without trend. Therefore, the series can be said to be integrated of order 1, I (1). However, for IP growth rate, the null hypothesis of the presence of a unit root can only be rejected on second difference.

\section{Co-Integration Test}

Results Co-integration test was carried out to determine whether the independent and dependent variables were having a stationary linear combination in the long run. According to Dora, (2009) the purpose of a cointegration test is to examine whether variables in the system drift apart from each other and are individually stable $I(1)$ in the short run. If these variables are cointegrated, they will be expected to form a stationary relationship in the long run. According to Brooks (2008), if variables with differing orders of integration are combined, their combination will have an order of integration equal to the largest. Since unit root test results indicated that all the variables were integrated of order one, $I(1)$ the order of integration was taken to be one, I(1). (Kirui, Wawire, \& Onono, 2014). The BreuschGodfrey LM test with four lags length was performed in order to test null hypothesis of no serial correlation against alternative of serial correlation. The result is presented in the table 4.4.

Table 4.4:Co Integration Test Results

Breusch-Godfrey Serial Correlation LM Test:

\begin{tabular}{llll}
\hline \hline F-statistic & 1.052112 & Prob. F(4,103) & 0.3842 \\
Obs*R-squared & 4.396540 & Prob. Chi-Square(4) & 0.3550 \\
\hline \hline
\end{tabular}

\section{Source: Author's Computation}

With an F-statistic of 4.397 and a p-value of 0.355 which was more than $5 \%$ significant level, the null hypothesis was accepted and this confirmed that there was no serial correlation of the error term.

\section{Heteroscedasticity test}

The white test (Breusch-Pagan test for heteroskedasticity) was applied to the residuals of the model to find out if the variance of the error terms were constant. The null hypothesis of 
homoscedasticity of error term while the alternative hypothesis of heteroscedasticity of the error terms was tested and the results are reported in the table 4.5 below:

Table 4.5 Breusch-Pagan test for heteroskedasticity

Heteroskedasticity Test: Breusch-Pagan-Godfrey

\begin{tabular}{llll}
\hline \hline F-statistic & 0.403739 & Prob. F(4,107) & 0.8056 \\
Obs*R-squared & 1.665285 & Prob. Chi-Square(4) & 0.7970 \\
Scaled explained SS & 3.663773 & Prob. Chi-Square(4) & 0.4534 \\
\hline
\end{tabular}

\section{Source: Author's Computation}

The result showed an F-statistic of 1.665 and a p-value of 0.797 which was more than 5\% significant level, the null hypothesis was accepted and this confirmed that there was no heteroskedasticity of the error term.

\section{Normality test}

Islam and Ahmed (1999) and Takaendesa (2006) observed that normality test was not a most important test after a model has passed the serial correlation and the heteroscedasticity tests. Nevertheless, the Jarque Bera normality test was used in this study to test normality of residuals. The JB test was based on the null that the residual was normally distributed against alternative hypothesis that residual was not normally distributed. The JB result indicates 42.981(0.1012), thus confirming that the residual was normally distributed because $P$ value was more than $5 \%$ significant level.

\section{Stability test}

The stability of the parameters of the OLS regression long run model was examined using the cumulative sum of the recursive residuals (CUSUM) tests proposed by Brown et al. (1975). The results of the stability tests are shown in Figures 4.2 below.

Figure 4.2: Stability test

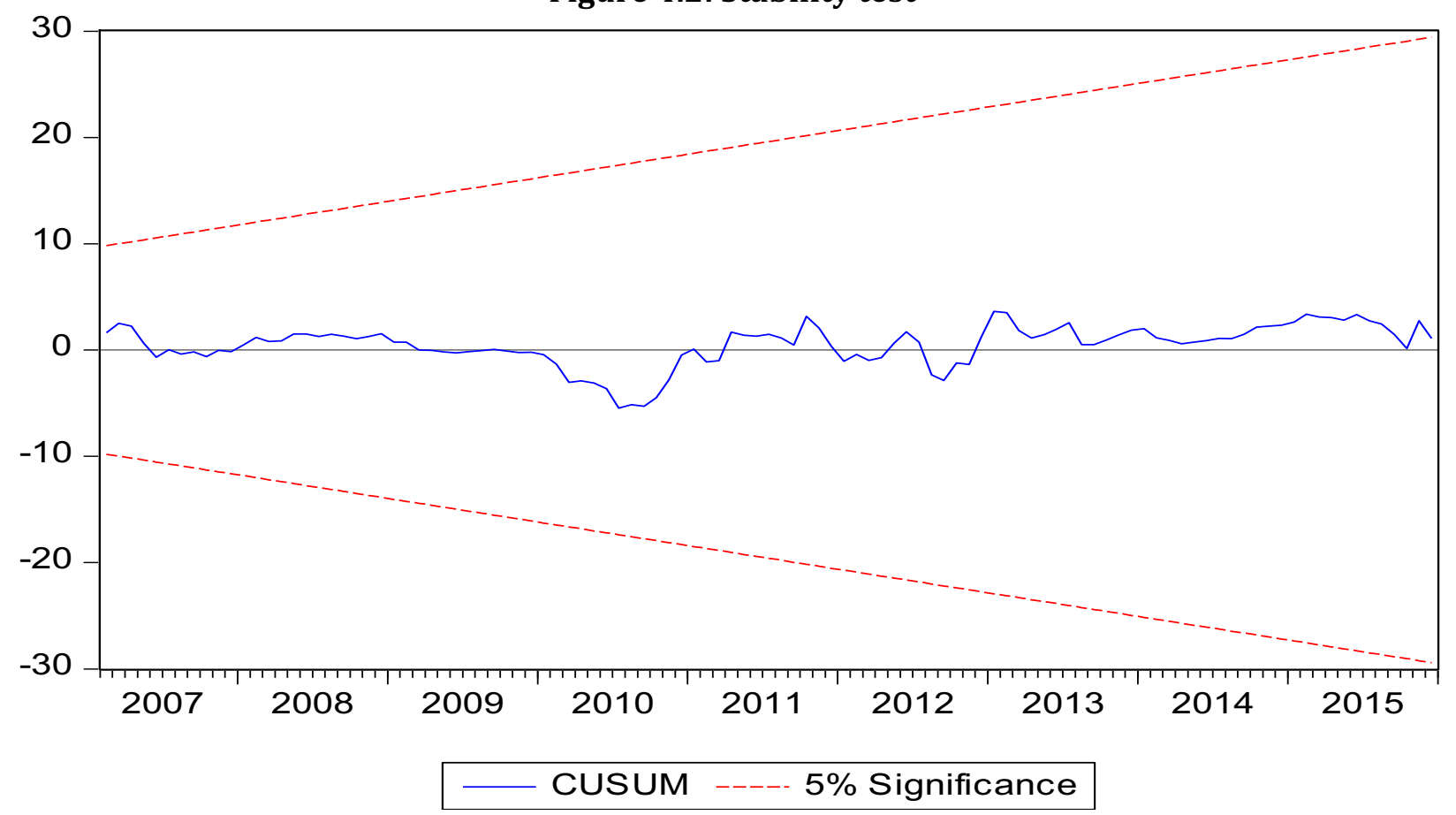


The results of Stability test show that the estimated OLS regression long run model was dynamically and structurally stable because the CUSUM statistic stayed within the $5 \%$ critical bound.

\section{Results of the entire time sample regressions}

Dependent Variable: D(YCORR)

Table 4.6 Results of the OLS regression equation

Method: Least Squares

Sample (adjusted): 2006M09 2015M12

Included observations: 112 after adjustments

\begin{tabular}{lllll}
\hline \hline Variable & Coefficient & Std. Error & t-Statistic & Prob. \\
\hline \hline D(INFL) & 0.106088 & 0.046557 & 2.278687 & 0.0247 \\
D(INT) & 0.176686 & 0.036311 & 4.865951 & 0.0000 \\
D(IP_GROWTH_RATE,2) & 0.029967 & 0.491377 & 0.060985 & 0.9515 \\
M3 & -0.060986 & 0.050560 & -1.206213 & 0.2304 \\
C & 0.079123 & 0.088698 & 0.892047 & 0.3744 \\
\hline \hline R-squared & 0.236084 & Mean dependent var & 0.008299 \\
Adjusted R-squared & 0.207527 & S.D. dependent var & 0.699199 \\
S.E. of regression & 0.622434 & Akaike info criterion & 1.933256 \\
Sum squared resid & 41.45433 & Schwarz criterion & 2.054618 \\
F-statistic & 8.266952 & Durbin-Watson stat & 1.803859 \\
Prob(F-statistic) & 0.000008 & & & \\
\hline \hline
\end{tabular}

\section{Source: Author's Computation}

Results in table 4.6 indicate Adjusted $\mathrm{R}^{2}$ is $21 \%$. This shows that $21 \%$ of the variations in the correlations of stock-bond returns are explained by Interest rates, Inflation, Industrial Production growth rate and Money Supply. The F-statistic is significant at all levels implying that the hypothesized relationship between the correlation of stock-bond returns and the selected macroeconomic variables is validated. The value of Durbin-Watson statistic is 1.8 implying that then model is not suffering from autocorrelation problem.

\section{Summary}

\section{SUMMARY, CONCLUSIONS \& RECOMMENDATIONS}

This study summarized the empirical findings as follows. Foremost, unit roots test of the variables was conducted using Augmented Dickey-Fuller (ADF) unit roots test. The ADF test found that all the variables were stationary at first difference except for IP which was non stationary both at I(0) and I(1). The Breusch - Godfrey serial correlation LM test was used to test for co-integration to determine whether the independent and dependent variables were having a stationary linear combination in the long run. The results showed an F-statistic of 4.397 and a p-value of 0.355 which was more than $5 \%$ significant level, the null hypothesis was accepted and this confirmed that there was no serial correlation of the error term.

The model was also tested for heteroscedasticity - if the variance of the error terms were constant- this was done using the white test (Breusch-Pagan test). The result showed an Fstatistic of 1.665 and a p-value of 0.797 which was more than 5\% significant level, the null hypothesis was accepted and this confirmed that there was no heteroskedasticity of the error term. The model passed both the normality and the stability tests. The study used the ordinary 
least squares regression model to estimate the relationship between the dependent and independent variables. The empirical result of the hypothesis tested showed that INFL, INT and IP had a positive influence to the stock bond correlation while M3 changes led to negative relationship between the two primary assets.

Inflation rate and interest rates had a positive relationship with the stock-bond return correlation. My results like the results of (Dimic, Kiviaho, Piljak, \& Äijö, 2014) show inflation as one of the long term determinants of stock-bond return correlations. The study also validates the findings by Li(2002) that the major trends in stock-bond correlation were determined primarily by uncertainty about expected inflation. On the impact of uncertainty about expected long-term inflation on stock-bond return correlation, Li (2002) shows that greater concerns about future inflation tend to result in stronger co-movements between stocks and bonds. About expected inflation rate, Li (2002) noted that similar to the real interest rate, expected inflation moves stock and bond returns in the same direction.

Industrial production was found to have a positive influence on stock-bond return correlation in this study. This is consistent with the findings of Dimic et al (2014) who found business cycle to be the third influential macroeconomic factor for the stock-bond correlation in the long run, appearing significant in eight emerging markets under their review. Estimated coefficients of the industrial production index were positive and statistically significant in seven countries. The fourth determinant, money supply was found to have a negative influence to stock -bond return correlation contrary to the findings of Dimic et al (2014) and (Durnez, 2016). This finding therefore validates the assertion that, depending on the effect of money supply on the inflation and real interest rates, the two components that govern the stock-bond covariance: unexpected shocks of the real interest rate will drive returns of stocks and bonds in the same direction, and that expected inflation will increase excess stock returns and lower excess bond returns (Campbell \& Ammer, 1993).

\section{Conclusions}

This paper investigated how macroeconomic factors affect the correlation between stock and bond returns in Kenya over the past decade (July2006-Dec2015) using the Arbitrage Pricing Theory (APT) and Capital Asset Pricing Model (CAPM) framework for a time series of data. The study aimed to validate that the correlation of stock and bond returns could be explained by their common exposure to macroeconomic factors. The link between the stock-bond correlation and macroeconomic factors was examined using OLS regression model. With the empirical tests aimed at answering the following questions: How does inflation affect the correlation between stock and bond returns in Kenya? How do the interest rates affect the correlation between stock and bond returns in Kenya? How does money supply affect the correlation between stock and bond returns in Kenya? And how does the business cycle affect the correlation between stock and bonds?

Secondary data obtained from the Kenya Central Bank, the Nairobi securities exchange and the Kenya bureau of statistics from July 2006 -December 2015 was analyzed. The empirical results confirmed that inflation rate, interest rate and business cycle do have a significant and positive influence on the stock-bond correlation. Money supply was found to have a negative influence on stock bond correlation in this study. The OLS regression Model confirmed long run relationship between stock-bond correlation and the macroeconomic variables under review. The model was found to be robust because it passed all the diagnostic tests. 


\section{Recommendations}

For Policy Making: This master's thesis contributes to monetary and fiscal policy formulation processes in emerging markets and more so in Kenya. Policy makers must exercise care when drawing up monetary policy involving interest rates and other economic policy because these policies may affect inflation rates, M3 and IP and in turn affect yield spread between assets. The understanding of how the bonds and stocks work plus the awareness of the stock - bond market could further help to develop the markets in Kenya as lauded in the Kenyan capital markets and securities exchange master plans.

For Further studies: This study contributes to the existing literature in two ways. First, by testing the model on the full time sample, the study provided new evidence to the little existing literature about stockbond return correlation in emerging countries. In addition, this study has provided evidence on the possibility of time-varying relationships in emerging markets like Africa more so in Kenya. For more understanding of the effect of macroeconomic variables on stock-bond correlations, this study proposes that future studies may focus on the following areas: Kenya recently launched the M-Akiba bond, a further study to understand if M-Akiba bond yields are driven by macroeconomic factors and how the correlation between stock-bond has been impacted by the new entry. This study also recommends further research that compares how the macroeconomic factors reviewed herein influence stock-bond correlations across a region like the Sub-Saharan Africa with a wider set of data. Further research in this area could check the influence of political risk on the stock -bond correlation in Kenya. This will allow a review of structural breaks in the 2007/2008, 2013 and the 2017 pre and postelection periods and how investors allocate their assets during these periods.

\section{References}

Ahmed, Salman, \& Mirko. (2005). “Does Inflation Matter for Equity Returns?” . Journal of Asset Management, Vol. 6, No. 4, , 259-273.

Altay, E. (2003). The Effect of Macroeconomic Factors on Asset Returns: A Comparative Analysis of the German and the Turkish Stock Markets in an APT Framework. Martin-Luther-University Halle, Betriebswirtschafliche.

Andersson, M., Krylova, E., \& Vähämaa, S. (2008). Why does the correlation between stock and bond returns vary over time? Applied Financial Economics, Vol. 18, No. 2, , 139-151.

Aslanidis, N., \& Christiansen, C. (2014). Quantiles of the realized stock-bond correlation and links to the macroeconomy. Journal of empirical Finance 28, 321-331.

Baele, L., Bekaert, G., \& Inghelbrecht, K. (2010). The Determinants of Stock and Bond Return Comovements. The Review of Financial Studies, Vol. 23, No. 6, 2374-2428.

Barsky, R. (1989). Why Don't the Prices of Stocks and Bonds Move Together? American Economic Review, 79, 1132-1145.

Bibow, J. (2005). Liquidity Preference Theory Revisited-To Ditch or to Build on It? Working Paper No. 427 The Levy Economics Institute of Bard College.

Campbell, J. Y., \& Ammer, J. (1993). What moves the stock and bond markets? a variance decomposition for long term asset returns. Journal of Finance, 48, 3-37.

Campbell, J., Lettau, M., Malkiel, B., \& Xu, Y. (2001). "Have Individual Stocks Become More Volatile? An Empirical Exploration of Idiosyncratic Risk.". Journal of Finance, 56 , 1-43.

Carr , J., \& Smith , L. B. (1972). Money Supply, Interest Rates, and the Yield Curve . Journal of Money, Credit and Banking , Vol. 4, No. 3 , 582-594.

Chui, C. M., \& Yang, J. (2012). Extreme correlation of stock and bond futures markets: international evidence. Financial Review, 47(3),, 565-587.

Dimic, N., Kiviaho, J., Piljak, V., \& Äijö, J. (2016). Impact of financial market uncertainty and macroeconomic factors on stock-bond correlation in emerging markets. Research in International Business and Finance 36, 41-51. 
Eun, C. S., Huang, W., \& Lai, S. (2008). International diversification with large and small-cap stocks. Journal of Financial and Quantitative Analysis, 43(02),, pp. 489-524.

Fah, F. C. (2008). Macroeconomics determinants of Malaysia government securities (MGS) spread. Paper presented during Proceeding of the MFA Conference 2008. Kuching, Sarawak.

Fama, F. E., \& Schwertz, G. W. (1977). Asset Returns and Inflation. Journal of Financial Economics 5(2), 115-46.

Garcia, V. F., \& Liu, L. (1999). Macroeconomic Determinants of Stock. . Journal of Applied Economics, 2(1), 29-59.

Graham, M., Kiviaho, J., \& Nikkinen, J. (2012). Integration of 22 emerging stock markets: a three-dimensional analysis. Global Finance Journal 23(1), 34-47.

Gulko, L. (2002). Decoupling. The Journal of Portfolio Management, 28(3),, pp. 59-66.

Hall, G. J., \& Krieger, S. (2000). The Tax Smoothing Implications of the Federal Debt Paydown. Brookings Papers on Economic Activity, 2.

Hull, J. C. (2012). Risk Management and Financial Institutions, third edition. John Wiley \& Sons, .

Ilmanen, A. (2003). Stock-Bond Correlations. Journal of Fixed Income vol. 13, no. 2, 55-66.

Kenya National Bureau of statistics. (2016). Economic Survey 2016. Nairobi.

Keynes, J. M. (1971-1989). The collected writings of John Maynard Keynes, 30 Volumes, General editors Donald E Moggridge and Elizabeth S Johnson, . London: Macmillan and New York: Cambridge University Press for the Royal Economic Society.

Kirui, E., Wawire, N. H., \& Onono, P. O. (2014). Macroeconomic Variables, Volatility and Stock Market Returns: A Case of Nairobi Securities Exchange, Kenya . International Journal of Economics and Finance; Vol. 6, No. 8;.

Levišauskaite, K. (2010). Investment Analysis and Portfolio Management. Leonardo da Vinci programme project.

Li, L. (2002). Macroeconomic Factors and the Correlation of Stock and Bond Returns. International Center for Finance Yale University.

Longin, F., \& Solnik, B. (2001). Extreme correlation of international equity markets. The Journal of Finance, 56(2),, 649-676.

Magnus A. et al, E. K. (2008). Why does the correlation between stock and bond returns vary over time? Applied Financial Economics, Vol. 18, No. 2,, pp. 139-151.

Markowitz, H. (1959). Portfolio Selection: Efficient Diversification of Investments. New York: Wiley (2nd Ed.) Cambridge, MA: Basil Blackwell, 1991.

Maskay, B. (2007). Analyzing the Effect of Change in Money Supply on Stock Prices. The Park Place Economist, Volume XV.

Maslov, S., \& Roehner. (2004). The conundrum of stock versus bond prices. Physica A: Statistical Mechanics and its Applications 335(1), pp. pp. 164-182.

Mishkin, F. S. (1992). “Is the Fisher Effect for Real? Journal of Monetary Economics, Vol. 30, No. 2, $195-215$.

Murzaieva, L. (2013). LINKAGES BETWEEN STOCK AND BOND MARKETS: EVIDENCE FROM RUSSIA. Thesis submitted to Kyiv School of economics.

Mutuku, C. (2015). Macroeconomic Variables and the Kenyan Equity Market: A Time Series Analysis. Business and Economic Research Vol. 5, No. 1.

Ngugi, R., Amanja, D., \& Maana, I. (2006). Capital Markets, Financial Deepening and Economic Growth In Kenya. International Journal of reserach in commerce, Economics \& Management.

Odero, W., Reeves, W., \& Kipyego, N. (2015). Kenya.

http://www.africaneconomicoutlook.org/fileadmin/uploads/aeo/2015/CN_data/CN_Long_EN/Kenya_GB_2015.p df: UNDP African Economic Outlook.

Ologunde, A. O., Elumilade, D. O., \& Asaolu, T. O. (2006). Stock Market Capitalization and Interest Rate in Nigeria: A Time Series Analysis. International Research Journal of Finance and Economics(No. 4),, 154-166.

Olweny, T., \& Omondi, K. (2011). The Effect of Macro-Economic Factors on Stock Return Volatility in the Nairobi Stock Exchange, Kenya. Economics and Finance Review Vol. 1(10), pp. 34 - 48,

Ouma, N. W. (2014). THE IMPACT OF MACROECONOMIC VARIABLES ON STOCK MARKET RETURNS IN KENYA. International Journal of Business and Commerce Vol. 3, No.11, 01-31. 
Panchenko, V., \& Wu, E. (2009). Time-varying market integration and stock and bond return concordance in emerging markets. Journal of Banking \& Finance 33(6), pp. 1014-1021.

Reilly, F., \& Brown, K. (2000). Investment Analysis and Portfolio Management. Dryden Press.

Richards, A. (1996). Volatility and predictability in national stock markets: How do emerging and mature markets differ? Staff Papers-International Monetary Fund, 461-501.

Saleem, K. (2011). Time Varying Correlations between Stock and Bond Returns: Empirical Evidence from Russia. Asian Journal of Finance \& Accounting Vol. 3, No. 1: E5.

Schwert, W. G. (1989). Why Does Stock Volatility Change Over Time? Journal of Finance 44: 11, 15-53.

Sellin, P. (2001). Monetary Policy and the Stock Market: Theory and Empirical Evidence. Journal of Economic Surveys 15 (4),, 491-541.

Shiller, R., \& Beltratti, A. (1992). Stock prices and bond yields:Can their Comovement be explained in terms of present value models? Journal of Monetary Economics 30, 25-26.

Shrestha, M. (2015). Time Varying Conditional Correlation between Stock and Bond Returns - Evidence from CIVETS.

Yang, Y., Zhou, Y., \& Wang, Z. (2009). The stock-bond correlation and macroeconomic conditions: one and a half centuries of evidence. Journal of banking and Finance 33, 670-680.

Yartey, C. A., \& Adjasi, C. K. (2007). Stock Market Development in Sub-Saharan Africa: Critical Issues and Challenges. IMF Working Paper No. 07/209.

Zhou, A., \& Jeske, K. (2012). Unexpected Inflation Hedging:A 3D SUPER Approach. San Francisco: Mellon Capital Management Corporation.

Zhu, B. (2012). The Effects of Macroeconomic Factors on Stock Return of Energy Sector in Shanghai Stock Market. International Journal of Scientific and Research Publications, Volume 2, Issue 11,. 